\title{
FLORISTIC COMPOSITION AND REGENERATION STATUS OF Emblica officinalis GAERTN. IN TWO SEMI-EVERGREEN FOREST STANDS OF MANIPUR, INDIA
}

\author{
Laishram Lilabati, Uttam Kumar Sahoo*, UttamThangjam
}

Department of Forestry, School of Earth Sciences \& Natural Resource Management, Mizoram University, Aizawl-796004, India

Received - March 05, 2018; Revision - May 19, 2018; Accepted - June 11, 2018

Available Online - June 20, 2018

DOI: http://dx.doi.org/10.18006/2018.6(3).563.571

\section{KEYWORDS}

Emblica officinalis

Floristic composition

Semi-evergreen forest

Regeneration

\begin{abstract}
The present study deals with the floristic composition and regeneration status of Emblica officinalis Gaertn. in two forest stands viz., Laimaton \& Zaujangtek of Manipur, India. Total 24 species belonging to 19 families and 23 genera at Laimaton and 21 tree species belonging to 12 families and 20 genera at Zaujangtek in the woody layer were recorded. The woody layer was dominated by Quercus serrata Murray in both the stands. The density of the trees was conspicuously higher (781 individuals/ha $\left.{ }^{-1}\right)$ at Laimaton forest stand than Zaujangtek forest stand (483 individuals $/ \mathrm{ha}^{-1}$ ). Peilou's Evenness index revealed more consistency in species distribution at Zaujangtek forest stand. Shannon's Species Diversity Index showed that a relatively higher diversity $\left(H^{\prime}=2.91364\right)$ at Laimaton forest stand than Zaujengtek stand $\left(\mathrm{H}^{\prime}=2.82724\right)$. The dominance diversity curve for the woody layer in both the forest stand showed normal distribution pattern of the species.
\end{abstract}

* Corresponding author

E-mail: uksahoo_2003@rediffmail.com; uttams64@gmail.com (Uttam Kumar Sahoo)

Peer review under responsibility of Journal of Experimental Biology and Agricultural Sciences.

Production and Hosting by Horizon Publisher India [HPI] (http://www.horizonpublisherindia.in/).

All rights reserved.
All the article published by Journal of Experimental Biology and Agricultural Sciences is licensed under a Creative Commons Attribution-NonCommercial 4.0 International License Based on a work at www.jebas.org.

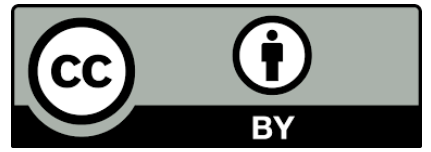




\section{Introduction}

Emblica officinalis Gaertn. is an important non-timber forest product (NTFP) deciduous tree species, grows in humid tropical environment, mostly dispersed in evergreen forests and native to tropical South Eastern Asia, Particularly Central, Southern and North eastern India (Firminger, 1947), ascending to $1450 \mathrm{~m}$ in the Himalayas (Brandis, 1906). The medicinal properties of this species have been well reported by many authors (Bhattacharya et al., 2000; Jose et al., 2001; Nosal'ova et al., 2003; Perianayagam et al., 2004; Scartezzini et al., 2006; Yokozawa et al., 2007; Sumitra et al., 2009; Gaire \& Subedi, 2014), its fruits are diuretic and laxative and useful in the disorder associated with the digestive system and are also prescribed in the treatment of jaundices and coughs (Krishnaveni \& Mirunalini, 2010; Kulkarni \& Ghurghure, 2018). The diverse use of this species is one of the reasons for its excessive harvest from the natural population. Anthropogenic disturbances are reported to bring changes in the overall community structure of a forest (Shafroth et al., 2002) which in turn can ultimately affect community and population dynamics. The importance of disturbances for maintaining community composition (Gross et al., 1998; Elderd, 2003) and determining population dynamics (Smith et al., 2005) has been well recognized in the tropical and extra-tropical systems.

Ngariyan hill biodiversity in Manipur, India is severely threatened by natural and anthropogenic disturbances (Sudhar Reddy, 2013; Singh et al., 2018). Over the years, the forests in the hills are under pressure through continuous extraction of timber, fuel wood, bamboo and collection of other non-timber forest products by the forest dependent people living in and around the forests. Human interferences are nevertheless critical factors which regulate the spatial and temporal pattern of vegetation in an ecosystem (Chapin et al., 1993). Determining composition, structure and function of a forest ecosystem is of great ecological value for understanding not only energy flow within the ecosystem but will also serve as an indicator of ecological impact. Forest diversity is the main income source for the people living in Ngariyan hill range, among these E. officinalis fruit is most commonly explored for the livelihood. Thus the level of extraction, need of the local people and other anthropogenic activities are likely to affect the floristic composition and vegetation structure of this hill range (Lalfakawma et al., 2009). Hence, an accurate data on biodiversity of this area is essential for proper management and conservation.

Although large number of studies are undertaken on the nutritional and medicinal aspects of E. officinalis (Nosal'ova et al. 2003; Maurya \& Srivastava 2011) but information on the population structure of $E$. officinalis is not well reported (Srivasuki, 2012; Prakash et al., 2012). Besides this, the regeneration status would provide indication on future compositional change of the species to the forests. The objective of this paper were to assess the floristic composition and the regeneration status of E. officinalis, in two forest stands subjected to anthropogenic disturbance, in Manipur, India.

\section{Materials and Methods}

Present study was conducted in Ngariyan hill range of Senapati district of Manipur, India involving two forests stands located around Laimaton and Zaujangtek village (Figure 1), these two villages were subjected to anthropogenic disturbances. The forest sites for Laimaton village being mildly disturbed (disturbance index 40\%) while it is highly disturbed for Zaujangtek village (disturbance index 70\%), this disturbance index was calculated on the basis of the ratio of the number of cut stump to the total stump present in the site (Bhuyan et al., 2003). The woody layer was analyzed by lying transect $(500 \mathrm{~m}$ length $\mathrm{x} 10 \mathrm{~m}$ width) in each site, wherein 20 permanent quadrats $(10 \times 10 \mathrm{~m})$ were randomly laid for phytosociological analysis. All the individuals $\geq 10 \mathrm{~cm}$ girth at breast height (gbh) at $1.37 \mathrm{~m}$ from ground layer were enumerated and were taken to calculate the basal area of the tree. The phytosociological analysis was done by following standard methods given by Misra (1968) and Mueller-Dombois \& Ellenberg (1974). The frequency, density and importance value index (IVI) of all observed species were calculated. Tree species diversity index $\left(H^{\prime}\right)$; Concentration of dominance of trees $(C d)$; Tree species richness index $(S R I)$ and evenness index $(E)$ was calculated by using the formula as given below:

a) 1963):

Shannon-Weiner diversity index, $H^{\prime}$ (Shannon \& Weiner,

$$
H^{\prime}=-\sum_{5=1}^{s} p i \ln p i
$$

Where, $H^{\prime}$ is the Shannon-Weiner diversity index, $p i$ is the proportion of individuals in the $i^{\text {th }}$ species i.e. (ni/N).

b)

$$
\text { Simpson Index of Dominance, } C d \text { (Simpson, 1949): }
$$

$$
C d=\sum_{i=0}^{n} \mathrm{p} i^{2}
$$

Where, $\mathrm{p}_{i}=$ proportion of individual in the $\underline{t}^{\text {th }}$ species.

c) Margalef richness index, SRI (Margalef, 1958):

$$
S R I=\frac{S-1}{\ln (N)}
$$

Where, $S$ is the total number of species, $N$ the number of individuals

d) Evenness index, E (Pielou, 1975):

$$
E=\frac{H^{\prime}}{\ln S}
$$

Where, $H^{\prime}$ is the Shannon-Weiner diversity index; $S$ is the total number of species. 


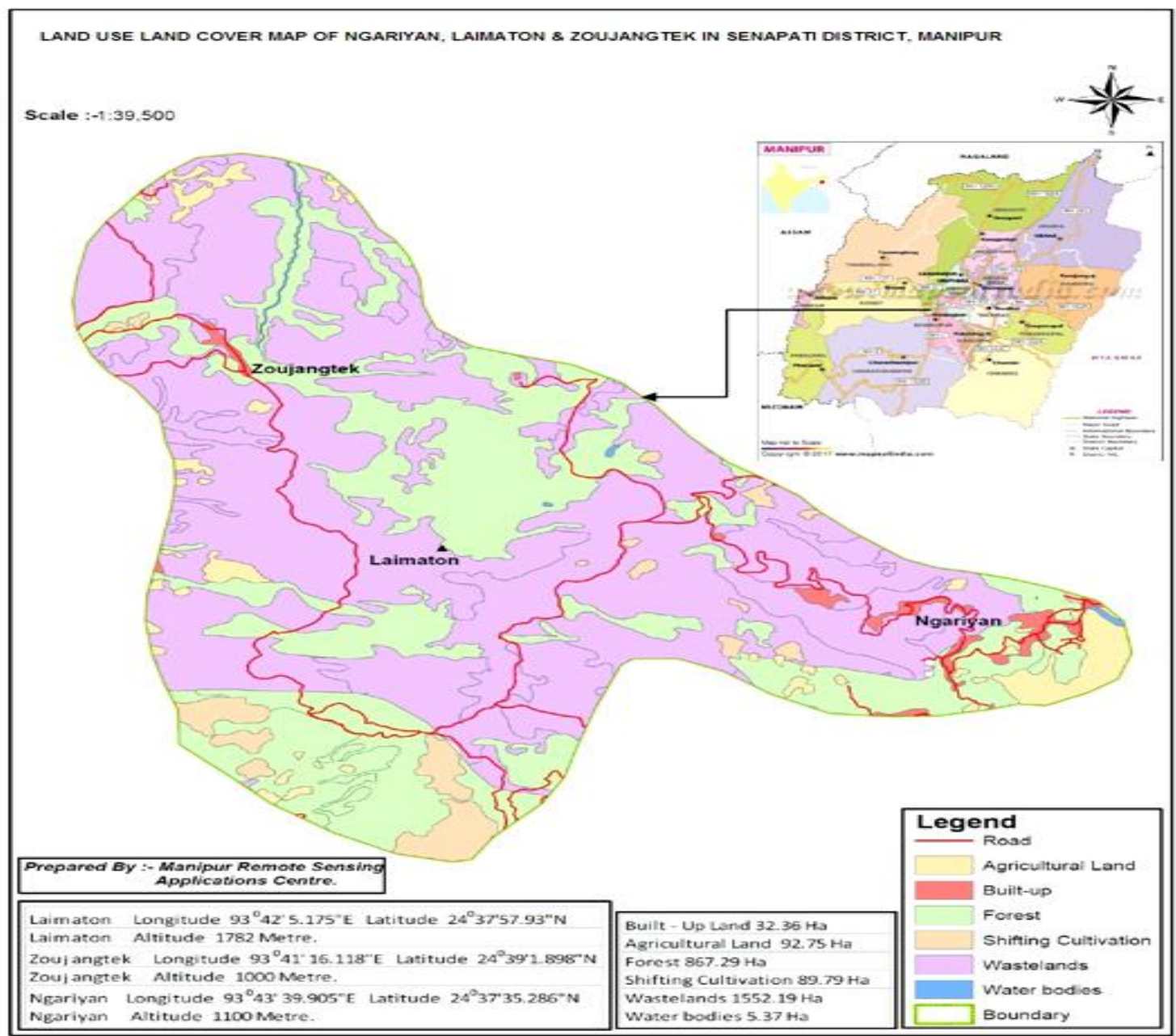

Figure 1 Map showing location of the study sites.

e)

Sorensen's similarity index (Sorensen, 1948):

$$
S=\frac{2 C}{A+B}
$$

Where, $\mathrm{S}=$ Sorensen's similarity coefficient; $\mathrm{A}=$ Number of species present in sample A; B = Number of species present in sample B; C = Number of species present in both samples

For studying the regeneration status of E. officinalis, 10 permanent plots of 0.1 ha $(100 \mathrm{~m} \times 10 \mathrm{~m})$ homogenous to the site were selected and sampled once a year. All the individuals belonging to seedlings and saplings were counted from each plot and their density was estimated. The seedlings and saplings encountered during the survey were divided into three categories; (i) short seedlings with $<10 \mathrm{~cm}$ height, (ii) medium seedling with $>10 \mathrm{~cm}$ to $20 \mathrm{~cm}$ height and (iii) tall seedlings with $>20 \mathrm{~cm}$ to $30 \mathrm{~cm}$ height. The sapling population was divided into two categories; (i) young saplings $(>30.0 \mathrm{~cm}$ height but $<10.0 \mathrm{~cm}$ circumference) and (ii) old saplings $(>10.0 \mathrm{~cm}$ to $30.0 \mathrm{~cm}$ $\mathrm{dbh})$. Those saplings $(>30 \mathrm{~cm} \mathrm{dbh})$ was considered as tree. The regeneration status of E. officinalis was determined based on the population size of seedlings, saplings and adults (Khan et al., 1987).

\section{Results}

\subsection{Floristic composition of woody layer}

A total of 24 species belonging to 19 families and 23 genera was reported from the Laimaton forest stand, whereas 21 tree species belonging to 12 families and 20 genera were reported from the Zaujengtek forest stand. In general, the woody layer consisted of both evergreen and deciduous broad-leaved trees, whose height did not reach beyond $25 \mathrm{~m}$. The woody layer was dominated by Quercus serrata in both the forest stand and this was followed by Gmelina 
arborea and Emblica officinalis (Table 1). Laimaton forest stand registered a higher density of tree height (782 individual's ha $\left.{ }^{-1}\right)$ in its woody layer than Zaujengtek forest stand (483 individual's ha ${ }^{-1}$ ) however; concentration of dominance was almost similar in both forest stands. Peilou's Evenness index reveals that Zaujengtek forest stand had slightly more consistency in species distribution (Table 2). Further, Shannon's species diversity index showed that Laimaton forest stand have relatively higher diversity $\left(\mathrm{H}^{\prime}=2.91364\right)$ than

Table 1 Floristic composition, basal area $\left(\mathrm{m}^{2} \mathrm{ha}^{-1}\right)$, density $\left(\mathrm{ha}^{-1}\right)$, importance value index (IVI) of woody layer two forest stands of Manipur.

\begin{tabular}{|c|c|c|c|c|c|c|}
\hline \multirow{2}{*}{ SPECIES } & \multicolumn{3}{|c|}{ LAIMATON FOREST STAND } & \multicolumn{3}{|c|}{ ZAUJANGTEK FOREST STAND } \\
\hline & Basal area & Density & IVI & Basal area & Density & IVI \\
\hline Aegle marmelos (L.) Correa & $0.19 \pm 0.004$ & 12.00 & 7.26 & - & - & - \\
\hline Albizia lebbeck (L.) Benth & $0.21 \pm 0.004$ & 18.00 & 8.21 & - & - & - \\
\hline Albizia stipulata (Roxb.) H.L Boivin & $0.42 \pm 0.004$ & 32.00 & 12.49 & $0.22 \pm 0.004$ & 16.00 & 13.15 \\
\hline Artocarpus lakoocha Roxb. & $0.19 \pm 0.003$ & 14.00 & 7.09 & - & - & - \\
\hline Bauhinia purpurea $\mathrm{L}$. & $0.23 \pm 0.01$ & 19.00 & 7.08 & $0.25 \pm 0.01$ & 17.00 & 13.79 \\
\hline Bombax ceiba $\mathrm{L}$. & $0.34 \pm 0.005$ & 15.00 & 9.61 & - & - & - \\
\hline Callicarpa arborea Roxb. & $0.22 \pm 0.005$ & 17.00 & 8.71 & - & - & - \\
\hline Castanopsis hystrix Hook. f. \& Thomas ex A.DC. & $0.56 \pm 0.01$ & 49.00 & 16.54 & $0.38 \pm 0.01$ & 33.00 & 17.27 \\
\hline Cinnamomum tamala Nees & - & - & - & $0.19 \pm 0.005$ & 13.00 & 11.99 \\
\hline Cinnamomum zeylanicum (Nees). & $0.26 \pm 0.01$ & 26.00 & 10.72 & $0.08 \pm 0.004$ & 6.00 & 4.87 \\
\hline Dipterocarpus tuberculatus Roxb. & $0.31 \pm 0.01$ & 28.00 & 11.49 & $0.09 \pm 0.004$ & 8.00 & 6.38 \\
\hline Emblica officinalis Gaertn. & $1.29 \pm 0.02$ & 90.00 & 28.89 & $0.59 \pm 0.01$ & 42.00 & 26.37 \\
\hline Erythrina suberosa Roxb. & $0.15 \pm 0.004$ & 9.00 & 5.05 & - & - & - \\
\hline Eucalyptus globulesLabill & - & - & - & $0.10 \pm 0.01$ & 6.00 & 5.22 \\
\hline Ficus semicordata Buch. Ham. Ex Roxb. & $0.38 \pm 0.01$ & 23.00 & 10.49 & - & - & - \\
\hline Gmelina arborea Roxb. & $1.13 \pm 0.01$ & 92.00 & 27.59 & $0.56 \pm 0.02$ & 37.00 & 23.25 \\
\hline Grewia microcos $\mathrm{L}$. & - & - & - & $0.63 \pm 0.02$ & 37.00 & 23.52 \\
\hline Grevillea robusta A Cunn. ex R. Br. & - & - & - & $0.09 \pm 0.004$ & 4.00 & 4.59 \\
\hline Litsea polyantha Juss. & $0.29 \pm 0.002$ & 23.00 & 10.62 & $0.18 \pm 0.01$ & 13.00 & 10.28 \\
\hline Michelia champaca $\mathrm{L}$. & $0.32 \pm 0.01$ & 21.00 & 10.63 & - & - & - \\
\hline Parkia roxburghii G. Don & - & - & - & $0.19 \pm 0.01$ & 11.00 & 10.72 \\
\hline Pasania pachyphylla (Kurz) Schottky & $0.67 \pm 0.01$ & 54.00 & 17.81 & $0.56 \pm 0.01$ & 38.00 & 24.19 \\
\hline Phoebe hainesiana Brandis & $0.43 \pm 0.01$ & 29.00 & 11.76 & $0.66 \pm 0.02$ & 36.00 & 23.82 \\
\hline Pinus kesiya Royleex Gordon & $0.36 \pm 0.01$ & 31.00 & 12.29 & - & - & - \\
\hline Quercus serrata Murray & $1.31 \pm 0.02$ & 104.00 & 30.87 & $0.68 \pm 0.02$ & 52.00 & 26.96 \\
\hline Rhus semialata Murray & - & - & - & $0.27 \pm 0.01$ & 20.00 & 14.77 \\
\hline $\begin{array}{llll}\text { Schima wallichii (Korth) Bloembergen (Elm.) } \\
\text { Bloembergen }\end{array}$ & $0.36 \pm 0.01$ & 28.00 & 11.47 & $0.27 \pm 0.01$ & 19.00 & 13.14 \\
\hline Tectona grandis L. f. & $0.19 \pm 0.003$ & 16.00 & 8.24 & $0.18 \pm 0.004$ & 11.00 & 10.62 \\
\hline Toona ciliata M. Roem. & $0.44 \pm 0.01$ & 28.00 & 12.66 & $0.14 \pm 0.005$ & 11.00 & 9.25 \\
\hline Zanthoxylum acanthopodium DC. & $0.04 \pm 0.003$ & 4.00 & 2.39 & $0.09 \pm 0.01$ & 9.00 & 5.83 \\
\hline
\end{tabular}

Number given after \pm represent SEM

Journal of Experimental Biology and Agricultural Sciences

http://www.jebas.org 
Table 2 Consolidated details on the diversity index, concentration of dominance, stand density of the trees in the woody layer of two forest stands of Manipur, India

\begin{tabular}{|lc|c|}
\hline Parameters & $\begin{array}{c}\text { LAIMATON } \\
\text { FOREST STAND }\end{array}$ & $\begin{array}{c}\text { ZAUJANGTEK } \\
\text { FOREST STAND }\end{array}$ \\
\hline Number of family & 19 & 12 \\
\hline Number of genera & 23 & 20 \\
\hline Number of species & 24 & 21 \\
\hline Density (number of trees ha ${ }^{-1}$ ) & 782 & 483 \\
\hline Concentration of dominance & 0.06859 & 0.06888 \\
\hline Diversity index (H') & 2.91364 & 2.82724 \\
\hline Peilou's Evenness Index & 0.9168 & 0.92863 \\
\hline Species richness & 3.45249 & 3.23624 \\
\hline
\end{tabular}

Table 3 Population structure of E. officinalis in two forest stands of Manipur.

\begin{tabular}{|ccc|}
\hline \multirow{2}{*}{ Girth class $(\mathrm{cm})$} & \multicolumn{2}{c|}{ Individuals $\left(\right.$ Number ha $\left.{ }^{-1}\right)$} \\
& Laimaton Forest Stand & Zaujangtek Forest Stand \\
\hline $0-5$ & $83.00 \pm 13.00$ & $69.00 \pm 3.00$ \\
\hline $5-10$ & $19.00 \pm 1.00$ & $17.00 \pm 2.00$ \\
\hline $10-15$ & $14.00 \pm 1.00$ & $7.00 \pm 0.00$ \\
\hline $15-20$ & $18.00 \pm 1.00$ & $10.00 \pm 1.00$ \\
\hline $20-25$ & $10.00 \pm 1.00$ & $7.00 \pm 0.00$ \\
\hline $25-30$ & $22.00 \pm 2.00$ & $16.00 \pm 1.00$ \\
\hline$>30$ & $55.00 \pm 3.00$ & $32.00 \pm 2.00$ \\
\hline
\end{tabular}

Number given after \pm represent SEM
Zaujengtek stand $\left(\mathrm{H}^{\prime}=2.82724\right)$. The dominance diversity curve for the woody layer in both the forest stand showed normal distribution pattern of E. officinalis (Figure 2).

\subsection{Population structure and regeneration status of $E$. officinalis}

The girth class distribution of E. officinalis in both the forest stand is shown in Table 3. A higher number of individuals at each girth class were found at Laimaton forest stand than Zaujengtek forest stand. Among the girth class, the individuals having $>30 \mathrm{~cm}$ dbh were significantly $(\mathrm{P}<0.05)$ higher at Laimaton forest stand than Zaujengtek forest stand. The population density of seedlings and saplings also varied greatly between the stands and census (Table 4, Figure 3). The short and medium seedlings were always higher $(\mathrm{P}<0.05)$ at Laimaton forest stand as compared to the Zaujengtek forest stand. Similar results were obtained in case of young and old samplings of E. officinalis. The number of samplings $(10-30 \mathrm{~cm}$ gbh) too had a markedly $(\mathrm{P}<0.05)$ presence at Laimaton forest stand than Zaujengtek forest stand (Table 5). A higher proportion of seedlings were found at Zaujengtek forest stand while a reverse trend was found for the proportion of trees in this stand (Table 5).

Table 4 Population density (number $\mathrm{ha}^{-1}$ ) of seedlings and saplings of E. officinalis in both forest stand of Manipur, India

\begin{tabular}{|lcccc|}
\hline \multicolumn{1}{|c}{ REGENERATION STATUS } & \multicolumn{2}{c}{ LAIMATON FOREST STAND } & \multicolumn{2}{c|}{ ZAUJANGTEK FOREST STAND } \\
& $1^{\text {st }}$ census (2015) & $2^{\text {nd }}$ census (2016) & $1^{\text {st }}$ census (2015) & $2^{\text {nd }}$ census (2016) \\
\hline Short & Seedling & $65.00 \pm 20.07$ \\
Medium & $98.00 \pm 12.09$ & $71.00 \pm 10.27$ & $65.00 \pm 12.22$ & $50.00 \pm 4.22$ \\
Tall & $35.00 \pm 5.82$ & $54.00 \pm 6.53$ & $34.00 \pm 3.06$ & $23.00 \pm 3.00$ \\
\hline \multicolumn{5}{c}{ Saplings } \\
\hline Young & $16.00 \pm 3.39$ & $55.00 \pm 6.19$ & $30.00 \pm 6.32$ & $51.00 \pm 12.42$ \\
Old & $38.00 \pm 6.46$ & $46.00 \pm 11.18$ & $49.00 \pm 9.94$ \\
\hline
\end{tabular}

Number given after \pm represent SEM

Table 5 Regeneration status (number ha $^{-1}$ ) of E. officinalis in both the forest stands of Manipur.

\begin{tabular}{|c|c|c|c|c|}
\hline & $\begin{array}{l}\text { LAIMATON FOREST } \\
\text { STAND }\end{array}$ & $\begin{array}{c}\text { ZAUJANGTEK } \\
\text { FOREST STAND }\end{array}$ & F ratio & $\begin{array}{l}P \text { value } \\
(P<0.05)\end{array}$ \\
\hline \multicolumn{5}{|c|}{ Life stage of Emblica officinalis } \\
\hline Seedling (stems $<10 \mathrm{~cm} \mathrm{cbh)}$ ha $^{-1}$ & $147.00 \pm 17.07$ & $113.00 \pm 14.30$ & $10.54^{* * *}$ & 0.004 \\
\hline Sapling (stems $10-30 \mathrm{~cm}$ cbh) $\mathrm{ha}^{-1}$ & $118.00 \pm 11.53$ & $76.00 \pm 13.68$ & $0.07^{\mathrm{NS}}$ & 0.79 \\
\hline Tree (stems $>30 \mathrm{~cm}$ cbh) ha $^{-1}$ & $90.00 \pm 13.58$ & $42.00 \pm 9.64$ & $8.31 * *$ & 0.009 \\
\hline \multicolumn{5}{|c|}{ Proportion to total population density $(\%)$ ha $^{-1}$} \\
\hline Seedling & $41.41 \%$ & $48.92 \%$ & & \\
\hline Sapling & $33.24 \%$ & $32.90 \%$ & & \\
\hline Tree & $25.35 \%$ & $18.18 \%$ & & \\
\hline
\end{tabular}

\pm SEM $=$ Standard Error Mean, $*=$ Significant at $\mathrm{P}<0.05, * *=$ Significant at $\mathrm{P}<0.01,{ }^{\mathrm{NS}}=$ Not significant

Journal of Experimental Biology and Agricultural Sciences http://www.jebas.org 


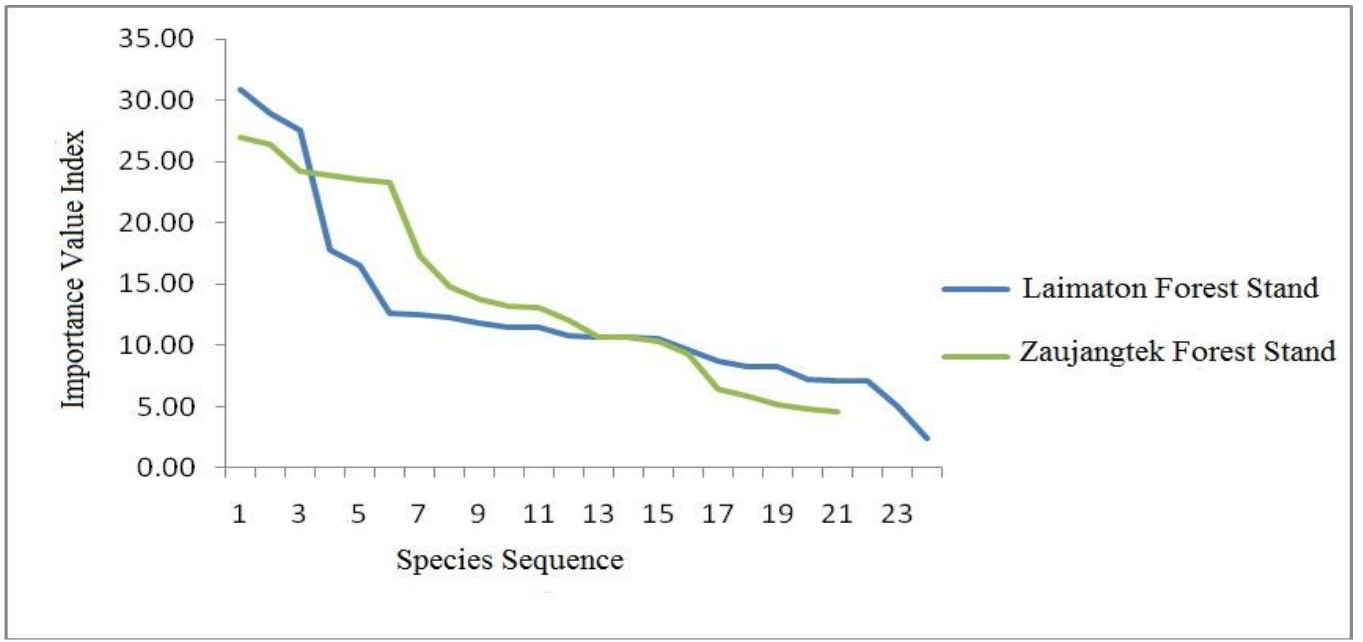

Figure 2 Dominance - diversity curve for woody layer in both the forest stands of Manipur, India

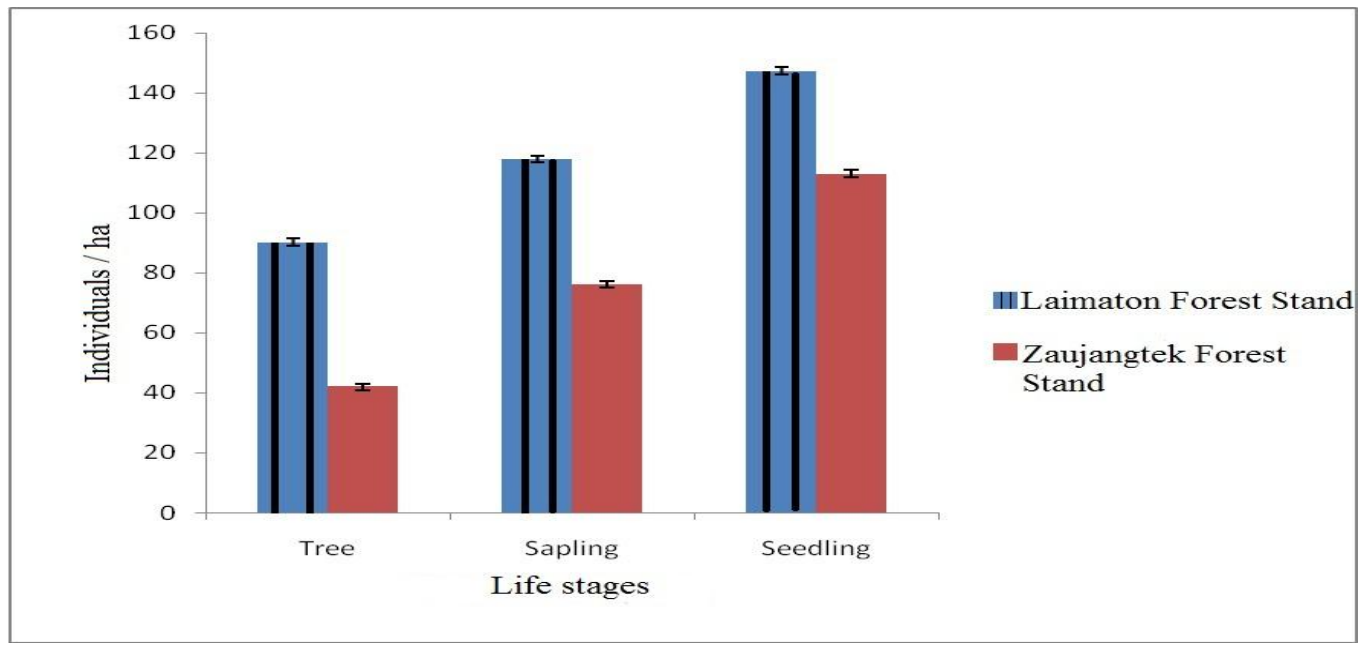

Figure 3 Mean density of tree, sapling and seedling of E. officinalis in both forest stand of Manipur, India

\section{Discussion}

The floristic compositions of both the forest stands are slightly varied. As expected the number of tree species was relatively higher at Laimaton forest stand than Zaujengtek forest stand and was related to the local disturbances that the sites received on account of felling of tree species. The role of locality factors in bringing change to community composition is well reported by various researchers (Walther et al., 2002; Parmesan \& Yohe, 2003; Theoharides \& Dukes, 2007; Panitsa et al., 2010; Majumdar \& Datta, 2015). The anthropogenic activities cause disturbance to the site leading to creation of different niches for the establishment and onward growth of tree seedlings. The species diversity and richness had a higher tendency in Laimaton forest stand as compared to Zaujengtek forest stand. On the contrary, Pilou's evenness index was higher in the Zaujengtek forest stand as compared to the Laimaton forest stand. According to Kumar \& Sahoo (2004) uncontrolled lopping and felling of trees for fuel wood, fodder forage and grazing, light conditions etc. can play prominent roles in contributing to species diversity. Tree fall gaps favours regeneration of many species enhancing species diversity (Brokaw \& Busing 2000; Schnitzer et al., 2000; Schnitzer et al., 2004). The dominance diversity curve in present study followed a normal distribution pattern indicating more equitable sharing of resources within the community. The IVI value of E. officinalis ranged from 2.39 to 30.87 which showed good regeneration. The population density of seedling of E. officinalis was significantly 
$(\mathrm{P}<0.05)$ higher at Zaujengtek forest stand than Laimaton forest stand, obviously due to canopy opening or canopy gaps caused because of high level of tree extraction in the former. Further, exposure to sunlight and water could be important reasons for regeneration, growth and development of this species (Seng et al. 2004).

Findings on the ranges of tree density among the two forest stands (483-781 trees ha ${ }^{-1}$ having $>30 \mathrm{~cm} \mathrm{dbh}$ ) are within those of estimate from other studies of tropical evergreen forest within India (294-1173 trees ha $^{-1}$ ) (Kumar et al. 2006). The density recorded in the present study was also closed to semi-evergreen forest of northeast India (685820 trees $\mathrm{ha}^{-1}$ in Manipur, Devi \& Yadava, 2006; 338-5452 trees ha ${ }^{-1}$ in Arunachal Pradesh, Bhuyan et al., 2003), Eastern Ghats (640-986 ha $^{-1}$, Kadavul \& Parthasarathy, 1999), south west India (635 trees ha ${ }^{-1}$, Pascal \& Pelissier, 1996) and in Andaman evergreen forests (1137 trees $\mathrm{ha}^{-1}$, Padalia et al., 2004) but were somewhat higher than the values reported by Hossain et al. (1997) 369 trees ha $^{-1}$, Nath et al. (1998), 381 stem ha $^{-1}$ and Biswas \& Misbahuzzaman (2008) 384 stem $\mathrm{ha}^{-1}$ in Bangladesh. Density of trees generally vary with forest community type, forest age, class, tree species and size class, site history, site condition and other factors. The studies carried outside India on tropical forest too showed a wide range of densities of trees > $30 \mathrm{~cm}$ gbh ranging from 98 trees $\mathrm{ha}^{-1}$ in Panamanian equatorial insular forests (Itow, 1986) to 1720 trees ha-1 in Amazonian tropical rain forests (Clark \& Clark, 2000; Clark et al., 2015). The tree density of present study area can compare well with that reported from other tropical forests. The Shannon-wiener values for tree species diversity in the present study ranged from 2.91364 and 2.82724 in mildly disturbed and highly disturbed respectively, which are quite high compared to 2.20-2.65 for the tropical forests of Kadayar in the Western Ghats of southern India (Sundarapandian \& Swamy, 2000). The diversity index for Indian forests ranged from 0.83 to 4.1 (Singh et al., 1984) and the value of diversity index of the present study therefore lies within the range and reflects high tree diversity in the study sites.

In general, both the sites registered good regenerations of E. officinalis reflected from the higher proportion of young individuals (seedling and saplings) compared to the old ones (trees). Good regeneration of this species indicates that the forest microclimate in both the sites was suitable for their regeneration. The presence of almost equal number of young and middle sized dbh class of the species indicate stable nature of these populations. However, there was a tendency of higher number of individuals in the intermediate class compared to lower and higher diameter class at Zaujengtek forest stand, which implies in an imbalance population structure and require urgent attention for management.

Increased seedling and sapling density at Laimaton forest stand than Zaujengtek forest stand may be due to enhanced seed availability and suitable microclimate. Nevertheless, this small scale disturbance that this site received increased the heterogeneity of forest floor, producing a variety of microclimate that favoured this co-existance of $E$. officinalis with other tree species in this site (Lusk, 1995; Christie \& Armesto, 2003), however, the proportion of seedlings and saplings decreased at Zaujengtek forest site, may be due to lack of sufficient seed availability coupled with absence of regeneration niches and safe site in this site, as also argued for other tree species (Pathak \& Shukla, 2004). Zaujengtek forest stand had lower number of tree, seedling and samplings compared to Laimaton forest stand, which clearly confirm that higher disturbance caused arrested growth of the saplings or delayed their establishment. The survival of the seedlings in this forest stand was poor which meant that the seeds reaching the ground were capable of germinating but failed to convert into early sapling stage due to high light and/or changing microclimate (Bankoti et al., 1986) and biotic influences (Duchok et al., 2005). This is further confirmed from a greenhouse experiment for the species which showed higher survival of seedling under partial shade than full sunlight (Lilabati \& Sahoo, 2016). The results of this study indicate that the disturbance may not only influence diversity but also regeneration and dominance of tree species. The findings of the study are therefore vital for understanding the community dynamics and for promoting species restoration programme in Ngariyan hill range of Manipur, Northeast India.

\section{Acknowledgements}

The first author (LL) wish to thank the University Grants Commission, New Delhi for providing financial grant to her in the form of a research fellowship to carry out this work. We also thank the people of Laimaton and Zaujengtek villages for providing logistic support to carry out this work.

\section{Conflict of Interest}

Authors declare that there is no conflict of interests arising from this study.

\section{References}

Kumar A, Bruce G, Marcot, Saxena A (2006) Tree species diversity and distribution patterns in tropical forests of Garo Hills. Current Science 91:10.

Bankoti TNS, Melkania U, Saxena AK (1986) Vegetation analysis along altitudinal gradient in Kumaun Himalaya. Indian Journal of Ecology 13: 211-222.

Bhattacharya A, Ghosak S, Bhattacharya SK (2000) Antioxidant activity of tannoid principles of Emblica officinalis (amla) in chronic stress induced changes in rat brain. Indian Journal of Experimental Biology 38: 877-880.

Bhuyan P, Khan ML, Tripathi RS (2003) Tree diversity and population structure in undisturbed and human - impacted stands of 
tropical wet evergreen forest in Arunachal Pradesh, Eastern Himalayas, India. Biodiversity and Conservation 12: 1753-1773.

Biswas SR, Misbahuzzaman K (2008) Tree species diversity and regeneration traits of the dominant species in a dipterocarpus forest in Bangladesh: Implications for conservation. International Journal of Biodiversity Science, Ecosystem Services \& Management 4: 81-91.

Brandis D (1906) Indian Trees Bishan Singh and Mahendra Pal Singh, Dehradun, Pp267.

Brokaw N, Busing RT (2000) Niche versus chance and tree diversity in forest gaps. Trends in Ecology and Evolution 15: 183-188.

Chapin FS, Moilanen L, Kielland K (1993) Preferential use of organic nitrogen for growth by a non-mycorrhizal arctic sedge. Nature 361 : $150-153$.

Christie DA, Armesto JJ (2003) Regeneration microsites and tree species coexistence in temperate rain forest of Chiloe Island, Chile. Journal of Ecology 91:776-784.

Clark DB, Clark DA (2000) Landscape-scale variation in forest structure and biomass in a tropical rainforest. Forest Ecology and Management 137: 185-198.

Clark DB, Hurtado J, Saatchi SS (2015) Tropical rain forest structure, tree growth and dynamics along a 2700-m elevational transect in

$\begin{array}{llll}\text { Costa } & \text { Rica. } & \text { ONE }\end{array}$ e0122905.https://doi.org/10.1371/journa;.pone.0122905.

Devi LS, Yadava PS (2006) Floristic diversity assessment and vegetation analysis of tropical semievergreen forest of Manipur, northeast India. Tropical Ecology 47: 89-98.

Duchok R, Kent K, Khumbongmayum AD, Paul A, Khan ML (2005) Population structure and regeneration status of medicinal tree Illicium griffithii in relation to temperate broad leaved forest of Arunachal Pradesh. Current Science 89: 673-676.

Elderd BD (2003) Changing flow regimes: its impacts on riparian vegetation and a common Riparian species, Mimulus guttatus. Ecological Applications 13: 1610-1625.

Firminger TA (1947) Firminger's manual of gardening for India, Thacker Spink Co. Ltd., Calcutta.

Gaire BP, Subedi L (2014) Phytochemistry, pharmacology and medicinal properties of Phyllanthus emblica Linn. Chinese Journal of Integrative Medicine 9: 1-8.

Gross K, Lockwood JR, Frost CC, Morris WF (1998) Modelling controlled burning and trampling reduction for conservation of Hudsonia Montana. Conservation Biology 12: 1291-1301.
Hossain MK, Hossain M, Alam MK (1997) Diversity and structural composition of trees in Bamu reserve forest of Cox's Bazar forest division, Bangladesh. Bangladesh Journal of Forest Science 26: 31-42.

Itow S (1986) Species diversity of equatorial insular forest on Ponape and Kosrae, Micronesia. Ecological Research 1: 223-227.

Jose JK, Kuttan G, Kuttam R (2001) Antitumour activity of Emblica officinalis. Journal of Ethnopharmacology 75: 65-69.

Kadavul K, Parthasarathy N (1999) Plant biodiversity and conservation of tropical semi-evergreen forest in Shervarayan hills of Eastern Ghats, India. Biodiversity and Conservation 8: 419-437.

Khan MA, Sankhla N, Weber DJ, McArthur ED (1987) Seed germination characteristics of Chrysothamnus nauseosus spp viridulus (Astereae, Asteraceae). Great Basin Naturalist 47: 220-226.

Kumar M, Sahoo UK (2004) Vegetation analysis of a temperate forest undergoing biotic pressure in Garhwal Himalayas. Journal of Nature Conservation 16: 381-387.

Krishnaveni M, Mirunalini S (2010) Therapeutic potential of Phyllanthus emblica (amla): the aryurvedic wonder. Journal of Basic Clinical Physiology Pharmacology 21: 93-105.

Kulkarni KV, Ghurghure SM (2018) Indian gooseberry (Emblica officinalis): complete pharmacognosy review. International Journal of Chemistry Studies 2: 5-11.

Lalfakawma, Sahoo UK, Roy S, Vanlalhluna PC (2009) Community composition and tree population structure in undisturbed and disturbed tropical semi-evergreen forest stands of North-east India. Applied Ecology and Environmental Research 7: 303-318.

Lilabati L, Sahoo UK (2016) Germination and growth behaviour of seedlings of Emblica officinalis Gaertn under different light and nutrient regimes in field conditions. Mizoram University Science and Technology Journal 4: 98-104.

Lusk CH (1995) Seed size establishment sites and species coexistence in a Chilean rain forest. Journal of Vegetation Science 6: 249-256.

Majumda K, Datta BK (2015) Cachar tropical semi-evergreen forest type of northeast India: status of species diversity, distribution and population structure. Proceedings of International Academy of Ecology and Environmental Sciences 5: 104-127.

Margalef R (1958) Information theory in ecology. General System 3: 36-71.

Maurya U, Srivastava S (2011) Traditional Indian herbal medicine used as antipyretic, antiulcer, antidiabetic and anticancer: A review. 
International Journal of Research in Pharmaceutical Chemistry 1: 1152-1159.

Misra R (1968) Ecology Work Book, Oxford publishing Company, Calcutta.

Mueller-Dombois D, Ellenberg H (1974) Aims and Methods of Vegetation Ecology, John Willey and Sons, USA.

Nath TK, Hossain M, Alam MK (1998) Diversity and composition of trees in Sitapahar forest reserve of Chittagong hill tracts (south) forest division, Bangladesh. Annals of Forestry 6: 1-9.

Nosal'ova G, Mokry J, Hasan KM (2003) Antitussive activity of the fruit extract of Emblica officinalic Gaertn, (Euphorbiaceae). Phytomedicine 10: 583-589.

Padalia H, Chauhan N, Porwal MC, Roy PS (2004) Phytosociological observations on tree species diversity of Andaman Islands. Current Science 87: 799-806.

Panitsa M, Trigas P, Latrou G, Sfenthourakis S (2010) Factors affecting plant species richness and endemism on land-bridge islands-An example from the East Aegean archipelago. Acta Oecologica 36: 431-437. Doi: 10.1016/j.actao.2010.04.004

Parmesan C, Yohe G (2003) A globally coherent fingerprint of climate change impacts across natural systems. Nature 421: 37-42.

Pascal JP, Pelissier R (1996) Structure and floristic composition of a tropical evergreen forest in south-west India. Journal of Tropical Ecology 12: 191-214.

Pathak SD, Shukla RP (2004) Population structure and sex-ratio of Mallotus philippensis Muel. Arg. Within forest vegetation of northeastern U.P., India. Tropical Ecology 45: 271-280.

Perianayagam JB, Sharma SK, Joseph A, Christina AJ (2004) Evaluation of anti-pyretic and analgesic activity of Emblica officinalis Gaertn. Journal of Ethnopharmacology 95: 83-85.

Pielou EC (1975) The measurement of diversity in different types of biological collections. Journal of Theoritical Biology 13: 131-144.

Prakash D, Upadhayay G, Gupta C, Pushpangadan P, Singh KK (2012) Antioxidant and fre radical scavenging activities of some promising wild edible fruits. International Food Research Journal 19: 1109-1116.

Scartezzini P, Antognoni F, Raggi MA, Poli F, Sabbioni C (2006). Vitamin $\mathrm{C}$ content and antioxidant activity of the fruit and of the Ayurvedic preparation of Emblica officinalis Gaertn. Journal of Ethnopharmacology 104: 113-118.

Schnitzer SA, Dalling JW, Carson WP (2000) The impact of lianas on tree regeneration in tropical forest canopy gaps: evidence for an alternative pathway of gap phase regeneration. Journal of Ecology 88: 655-666.

Schnitzer SA, Parren MPE, Bongers F (2004) Recruitment of Lianas into logging gaps and the effects of pre-harvesting climber cutting. Forest Ecology and Management 190: 87-98.

Seng HW, Ratnam W, Noor SM, Clyde MM (2004) The effects of timing and method of logging on forest structure in Peninsular Malaysia. Forest Ecology and Management 203: 209-228.

Shaforth PB, Stromberg JC, Patten DT (2002) Riparian vegetation response to altered disturbance and stress regimes. Ecological Applications 12: 267-275.

Shannon CE, Wiener W (1963) The mathematical theory of communities. University of Illinois press, Urbana.

Simpson EH (1949) Measurement of diversity. Nature 163:688.

Singh AR, Brahmacharimayum B, Yengkokpam SS, Vino RM, Bunii A, Khino Anal KT, Devi SR (2018) Current status of floral richness in phayeng community forests, Imphal west. Journal of Biodiversity Management \& Forestry 7: Doi: 10.4172/2327-4417.1000195.

Singh JS, Singh SP, Saxena AK, Ravat YS (1984) The forest vegetation of silent valley. Tropical rain forests. The Leeds Symposium, Pp. 25-52.

Smith M, Caswell H, Mettler-Cherry P (2005) Stochastic flood and precipitation regimes and the population dynamics of a threatened floodplain plant. Ecological Applications 15: 1036-1052.

Sorensen T (1948) A method for establishing groups of equal amplitude in plant sociology based on similarity of species content and its application to analyses of the vegetation on Danish commons. Iidenski Selskab Biologiske Skrifier 5: 1-34.

Srivasuki KP (2012) Nutritional and health care benefits of Amla. Journal of Pharmacognosy 3: 141-51.

Sudhar Reddy C (2013) Spatial pattern of forest fragmentation in Manipur, North East India: A case study using RS and GIS technique. International Journal of Earth Sciences and Engineering 6: 1713-1717

Sumitra M, Manikandan P, Gayathri VS, Mahendran P, Sugana L (2009) Emblica officinalis exerts wound healing action through upregulation of collagen and extracellular signal-regulated kinases $\left(\mathrm{ERK}_{1 / 2}\right)$. Wound Repaire and Regeneration 17: 99-107.

Sundarapandian SM, Swamy PS (2000) Forest ecosystem structure and composition along an altitudinal gradient in the Western Ghats, South India. Journal of Tropical Forest Science 12: 104-123.

Theoharides KA, Dukes JS (2007) Plant invasion across space and time: factors affecting non-indigenous species success during four stages of invasion. New Phytologist 176: 256-273. Doi: org/10.1111/j.14698137.2007.02207.x.

Walther GR, Post E, Convey P (2002) Ecological responses to recent climate change. Nature 416: 389-95.

Yokozawa T, Kim HY, Kim HJ, Okubo T, Chu DC, Juneja LR (2007) Amla (Emblica officinalis Gaern.) prevents dyslipidaemia and oxidative stress in the ageing process. The British Journal of Nutrition 97: 1187-1195. 